IRA-International Journal of Management \& Social Sciences

ISSN 2455-2267; Vol.07, Issue 02 (2017)

Pg. no. 131-137

Institute of Research Advances

http://research-advances.org/index.php/RAJMSS

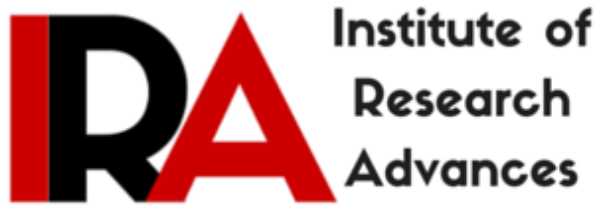

\title{
Financial Inclusion of Deprived Groups - A Study Conducted in Four Vulnerable Areas of Ernakulam District in Kerala
}

Krishnakumar U R

Assistant Professor, SNM College, Maliankara, Ernakulam Dt., Kerala State, India.

Type of Review: Peer Reviewed.

DOI: http://dx.doi.org/10.21013/jmss.v7.n2.p2

\section{How to cite this paper:}

U R, Krishnakumar (2017). Financial Inclusion of Deprived Groups - A Study Conducted in Four Vulnerable Areas of Ernakulam District in Kerala. IRA-International Journal of Management \& Social Sciences (ISSN 2455-2267), 7(2), 131-137.

doi:http://dx.doi.org/10.21013/jmss.v7.n2.p2

(C) Institute of Research Advances

\section{(c) EY-NC}

This work is licensed under a Creative Commons Attribution-Non Commercial 4.0

International License subject to proper citation to the publication source of the work.

Disclaimer: The scholarly papers as reviewed and published by the Institute of Research Advances (IRA) are the views and opinions of their respective authors and are not the views or opinions of the IRA. The IRA disclaims of any harm or loss caused due to the published content to any party. 


\begin{abstract}
Banking is an imperative force of Financial Inclusion. Financial Inclusion is coined as a process that ensures the ease of admittance, availability and usage of the formal financial system for all members of an economy including the deprived groups living in our society. This study mainly aims to assess the level of financial inclusion among the deprived groups who are living in Ernakulam Dt. Of Kerala State. This research work also intends to know the consciousness of the respondents as regards the financial inclusion, and financial products and services offered by banks. This study implemented in four rural underdeveloped areas in Ernakulam District ie Kodanad, Kuttampuzha, Panagad and Chellanam. All these are highly backward areas in Ernakulam District. The respondents are selected at random from these areas. Forty respondents are selected from each group at a total of 160 respondents. The main tool used for collecting data is interview schedule. The finishing part of the study reveals that the financial inclusion practices of these selected areas are acceptable.
\end{abstract}

Key words: - Vulnerable groups, Financial Inclusion, Financial Services.

\title{
Introduction
}

An extremely relatable and paradoxical question, can a well developed financial system serve the poor and those who are socially excluded? It is an actuality that banking services are in the nature of public goods. It is essential that availability of banking and payment services to the entire population without discrimination is the prime objective of public play and a key for achieving sustainability. Reserve Bank of India's vision for 2020 is to open nearly 600 million fresh customers accounts and serve them through a variety of channels by leveraging on Information Technology.

\section{Definition of Financial Inclusion}

Financial inclusion is the practice of ensuring access to appropriate financial products and services needed by vulnerable groups such as weaker sections and low income groups at an affordable cost in a fair and transparent manner by main stream institutional players.

\section{Operational Definition of Vulnerable group}

Vulnerable groups includes weaker sections and low income groups such as slum dwellers, marginal farmers, migrants, rural women, old aged people etc...

\section{Objectives of the study}

1. To evaluate the level of financial inclusion among the vulnerable sections of society in Ernakulam Dt.

2. To examine the level of awareness among the vulnerable sections of society in Ernakulam about financial inclusion financial products and services offered by the bank.

3. To provide apposite suggestions for overall development of vulnerable sections of society through financial inclusion.

\section{Research Methodology}

The present study was intended to assess the level of financial inclusion among the vulnerable section of society in Ernakulam Dt. and also to study their awareness about financial inclusion, financial products and services offered by the bank and to understand the difficulties faced by banks in the area of financial inclusion. Four vulnerable areas of Ernakulam Dt. are Kodanad, Kuttampuzha, Panangad and Chellanam and 40 respondents from each vulnerable area were randomly selected for the study. Face to face interview was conducted by using interview schedule to collect information from the respondents. Percentage was used to analyze data on demographic characteristics, level of financial inclusion and the awareness level of the respondents about financial inclusion, financial products and serves offered by the bank. 


\section{Review of Literature}

Goodwin D, Adelman L, Middleton S and Ashwath K (2000) accentuate the function of level of employment of a country as another important cause of financial inclusion. Access to affordable financial services especially credit and insurance, enlarges livelihood opportunities and empowers the poor to take charge of their lives.

Bekaert, Geert, Harvey Campbell R and Lundblad Christian (2005),, in their learning examined a upbeat impact of equity market liberalization on real economic development and upliftment of the vulnerable groups living in the society. Further they also observed the positive impact of capital account liberalization and quality of financial institutions on economic growth. They argued that better scaffolding to deprived group is very essential for the real growth of a country.

Sharma(2008), throughout cross country empirical study examined a slam rapport between financial inclusion and different - socio-economic variables like income, inequality, literacy, physical infrastructures.

\section{Results and Analysis}

The principle of financial inclusion is liberating banking services at an inexpensive price in a pale and transparent manner to the vulnerable groups of the society. The results and analysis of the data collected are depicted below.

\section{SOCIO- ECONOMIC STATUS OF THE RESPONDENTS}

Table No.1 unfolds that majority of the respondents are youth with an age group of 18 to 35 years. It is found that 70 percentage of the respondents in the areas were female. Lions part of the respondents were completed only primary level of their education. Mass of the respondents was working as labor worker. It is noted that vast of the respondents were belonging to family monthly income series of below five thousand.

Table No.1 Socio- Economic Profile of Respondents

\begin{tabular}{|c|c|c|c|c|c|c|c|c|c|}
\hline \multirow{3}{*}{\multicolumn{2}{|c|}{ Socio - Economic Variables }} & \multicolumn{8}{|c|}{ Respondents } \\
\hline & & \multicolumn{2}{|c|}{ Kodanad } & \multicolumn{2}{|c|}{ Kuttampuzha } & \multicolumn{2}{|c|}{ Panangad } & \multicolumn{2}{|c|}{ Chellanam } \\
\hline & & Nos. & $\%$ & Nos. & $\%$ & Nos. & $\%$ & Nos. & $\%$ \\
\hline \multirow[t]{5}{*}{ Age } & Below -25 & 15 & 37.5 & 13 & 32.5 & 8 & 20 & 16 & 40 \\
\hline & $26-35$ & 10 & 25 & 9 & 22.5 & 16 & 40 & 5 & 12.5 \\
\hline & $36-45$ & 5 & 12.5 & 7 & 17.5 & 6 & 15 & 5 & 12.5 \\
\hline & $46-50$ & 6 & 15 & 8 & 20 & 5 & 12.5 & 8 & 20 \\
\hline & Above -50 & 4 & 10 & 3 & 7.5 & 5 & 12.5 & 6 & 15 \\
\hline \multirow[t]{3}{*}{ Gender } & Male & 12 & 30 & 15 & 37.5 & 11 & 28 & 18 & 45 \\
\hline & Female & 28 & 70 & 25 & 62.5 & 29 & 72 & 22 & 55 \\
\hline & Trans Gender & - & - & - & - & - & - & - & - \\
\hline \multirow[t]{6}{*}{ Education } & Illiterate & 1 & 2.5 & 3 & 7.5 & 6 & 15 & 5 & 12.5 \\
\hline & Primary & 24 & 60 & 20 & 50 & 18 & 45 & 19 & 47.5 \\
\hline & High School & 8 & 20 & 12 & 30 & 12 & 30 & 6 & 15 \\
\hline & $\begin{array}{l}\text { Higher } \\
\text { Secondary }\end{array}$ & 5 & 12.5 & 4 & 10 & 2 & 5 & 6 & 15 \\
\hline & Graduate & 1 & 2.5 & 1 & 2.5 & 2 & 5 & 2 & 5 \\
\hline & Post Graduate & 1 & 2.5 & - & - & - & - & 2 & 5 \\
\hline
\end{tabular}




\begin{tabular}{|l|l|c|c|c|c|c|c|c|c|}
\hline & Other & - & - & - & - & - & - & - & - \\
\hline \multirow{5}{*}{ Occupation } & Small Business & 2 & 5 & 5 & 12.5 & 3 & 7.5 & 2 & 5 \\
\cline { 2 - 9 } & Job & 3 & 8 & 2 & 5 & 4 & 10 & 5 & 12.5 \\
\cline { 2 - 9 } & Labor & 25 & 62 & 21 & 52.5 & 24 & 60 & 22 & 55 \\
\cline { 2 - 9 } & Farmer & 10 & 25 & 12 & 30 & 9 & 22.5 & 11 & 27.5 \\
\hline $\begin{array}{l}\text { Monthly } \\
\text { Family }\end{array}$ & Below - 2500 & 3 & 8 & 11 & 27.5 & 8 & 20 & 5 & 12.5 \\
\cline { 2 - 9 } & $2501-5000$ & 22 & 55 & 13 & 32.5 & 15 & 37.5 & 23 & 57.5 \\
\cline { 2 - 9 } & $5001-7500$ & 11 & 27 & 13 & 32.5 & 12 & 30 & 9 & 22.5 \\
\cline { 2 - 9 } & Above -7500 & 4 & 10 & 3 & 7.5 & 5 & 12.5 & 3 & 7.5 \\
& & & & & & & & & \\
\hline
\end{tabular}

Source : Survey data

\section{FINANCIAL INCLUSION STATUS OF RESPONDENTS:-}

The standing of financial inclusion of the preferred respondents are discussed below.

A. Have a Bank Account.

Table No.2. Have a Bank Account

\begin{tabular}{|l|c|c|c|c|c|c|c|c|c|}
\hline & \multicolumn{9}{|c|}{ Respondents } \\
\cline { 2 - 11 } & \multicolumn{10}{|c|}{ Kuttampuzha } & \multicolumn{1}{|c|}{ Panangad } & Chellanam & All Area \\
\cline { 2 - 10 } & Kodanad & $\%$ & Nos. & $\%$ & Nos. & $\%$ & Nos. & $\%$ & Nos. \\
\hline Yes & 36 & 90 & 35 & 88 & 37 & 92 & 34 & 85 & $\mathbf{1 4 2}(\mathbf{8 9 \% )}$ \\
\hline No & 04 & 10 & 05 & 12 & 03 & 08 & 06 & 15 & $\mathbf{1 8}(\mathbf{1 1 \%})$ \\
\hline Total & 40 & 100 & 40 & 100 & 40 & 100 & 40 & 100 & $\mathbf{1 6 0}(\mathbf{1 0 0 \%})$ \\
\hline
\end{tabular}

Source: Survey datA

It is very much clear from table No.2, that is $89 \%$ of the surveyed respondents having a bank account, where as only a minor percentage (11\%) belongs to a category of not having a bank account.

B) Reason for not having a Bank Account

Table No.3. Reason for not having a Bank Account

\begin{tabular}{|l|c|c|c|c|c|c|c|c|c|}
\hline \multirow{2}{*}{ Particulars } & \multicolumn{9}{|c|}{ Respondents } \\
\cline { 2 - 13 } & Kodanad & \multicolumn{1}{|c|}{ Kuttampuzha } & \multicolumn{2}{l|}{ Panangad } & \multicolumn{2}{l|}{ Chellanam } & \multicolumn{2}{l|}{ All Area } \\
\cline { 2 - 12 } & Nos. & $\%$ & Nos. & $\%$ & Nos. & $\%$ & Nos. & $\%$ & Nos. \\
\hline Distance & - & - & - & - & - & - & - & - & - \\
\hline No Money to save & 3 & 75 & 3 & 60 & 3 & 100 & 4 & 67 & $13(72 \%)$ \\
\hline Lack of awareness & - & - & 1 & 20 & - & - & - & - & $1(6 \%)$ \\
\hline Lack of advice & 1 & 25 & 1 & 20 & - & - & 2 & 33 & $4(22 \%)$ \\
\hline No identity proof & - & - & - & - & - & - & - & - & - \\
\hline Lack of understanding & - & - & - & - & - & - & - & - & - \\
\hline Total & 04 & 100 & 05 & 100 & 3 & 100 & 06 & 100 & $18(100 \%)$ \\
\hline
\end{tabular}

Source: Survey data 
As regards the reason for not having a bank account, (table -3) majority of the respondents (72\%) from all area opines that no money to save is the major factor. The second serious reason is lack of advice $(22 \%)$ and the third case is recorded as lack of awareness $(6 \%)$. According to this table, Distance, No identity cards and lack of understanding were not the route cause for respondents in not opening a bank account.

\section{AWARENESS LEVEL OF THE RESPONDENTS ABOUT NO FRILL ACCOUNT.}

No frills account (NFA) is financial product which allows financially excluded individuals to access banking services for the purpose of savings and also had credit feature in the form of overdraft facility. It is vivid from table No. 4 that $64 \%$ of the respondents from four area having enough (64\%) awareness about BSBDA. (Basic Savings Bank Account)

Table No. 4. Awareness of No Frills A/c.

\begin{tabular}{|l|c|c|c|c|c|c|c|c|c|}
\hline & \multicolumn{9}{|c|}{ Respondents } \\
& \multicolumn{10}{|c|}{ Kuttampuzha } & Panangad & Chellanam & All Area \\
\cline { 2 - 10 } & Kodanad & Nos. & $\%$ & Nos. & $\%$ & Nos. & $\%$ & Nos. \\
\cline { 2 - 10 } & Nos. & $\%$ & 22 & 55 & 28 & 70 & 27 & 68 & $102(64 \%)$ \\
\hline Yes & 25 & 63 & 18 & 45 & 12 & 30 & 13 & 32 & $58(36 \%)$ \\
\hline No & 15 & 37 & 40 & 100 & 40 & 100 & 40 & 100 & $160(100 \%)$ \\
\hline Total & 40 & 100 & &
\end{tabular}

Source : Survey data

IV) SOURCE OF INFORMATION ABOUT NO FRILLS (BSBDA) ACCOUNT (NFA)

Table No. 5. Source of information about BSBDA

\begin{tabular}{|l|c|c|c|c|c|c|c|c|c|}
\hline & \multicolumn{9}{|c|}{ Respondents } \\
& \multicolumn{10}{|c|}{} & \multicolumn{10}{l|}{} \\
\cline { 2 - 12 } & Kodanad & Kuttampuzha & \multicolumn{2}{l|}{ Panangad } & \multicolumn{2}{l|}{ Chellanam } & All Area \\
\cline { 2 - 11 } & Nos. & $\%$ & Nos. & $\%$ & Nos. & $\%$ & Nos. & $\%$ & Nos. \\
\hline Media & - & - & - & - & - & - & - & - & - \\
\hline SHG & 02 & 08 & 01 & 05 & 01 & 04 & 01 & 04 & 05 \\
\hline Bank & 23 & 92 & 21 & 95 & 27 & 96 & 26 & 96 & 97 \\
\hline Others & - & - & - & - & - & - & - & - & - \\
\hline Total & 25 & 100 & 22 & 100 & 28 & 100 & 27 & 100 & $102(100 \%)$ \\
\hline
\end{tabular}

Source : Field work

Table No. 5 depicts that banking institution possess a decisive role in creating the awareness and spreading the message about NFA. The media and SHG was failed to act as a source of information, the role which they are invented to play.

All the customers have sufficient information about the savings and deposits of banks. In terms of pass book and cheque, around 91\% (129/142) of the customers have clear cut awareness. The understanding about loans and interest rates are very much closer to 82\%(117/142). It means, they have better idea about these services. Customer's awareness level of ATM and insurance schemes are very much pathetic. In terms of ATM, around 77\% (109/142) of the customers are not familiar about its working. The case of insurance services reveals that only $4 \%(05 / 142)$ of the customers having an adequate know- how of various schemes offered by the banks. From among the five variables of awareness level, all are satisfactory except ATM and insurance products.

V) AWARENESS LEVEL OF THE CUSTOMERS ABOUT FINANCIAL SERVICES OFFERED BY BANKS AFTER OPENING AN ACCOUNT

Table No. 6 Level of awareness among the customers

\begin{tabular}{|c|c|c|c|c|c|c|c|c|c|c|}
\hline \multirow{3}{*}{$\begin{array}{l}\text { Nature of } \\
\text { Financial } \\
\text { Services }\end{array}$} & \multirow{3}{*}{$\begin{array}{c}\begin{array}{c}\text { Level } \\
\text { of }\end{array} \\
\text { awareness }\end{array}$} & \multicolumn{9}{|c|}{ Respondents } \\
\hline & & Kodc & & Kutta & uzha & Panal & & Chella & & All area \\
\hline & & Nos. & $\%$ & Nos. & $\%$ & Nos. & $\%$ & Nos. & $\%$ & Nos. \\
\hline
\end{tabular}




\begin{tabular}{|c|c|c|c|c|c|c|c|c|c|c|}
\hline \multirow{2}{*}{$\begin{array}{l}\text { Savings } \\
\text { and } \\
\text { Deposits }\end{array}$} & Not familiar & - & - & - & - & - & - & - & - & - \\
\hline & $\begin{array}{l}\text { Just } \\
\text { Familiar }\end{array}$ & 36 & 100 & 35 & 100 & 37 & 100 & 34 & 100 & 142 \\
\hline \multirow[t]{2}{*}{$\begin{array}{l}\text { Pass book } \\
\text { and cheque }\end{array}$} & $\begin{array}{l}\text { Not } \\
\text { familiar }\end{array}$ & 4 & 11 & 1 & 03 & 5 & 14 & 3 & 09 & 13 \\
\hline & $\begin{array}{l}\text { Just } \\
\text { Familiar }\end{array}$ & 32 & 89 & 34 & 97 & 32 & 86 & 31 & 91 & 129 \\
\hline \multirow{2}{*}{$\begin{array}{l}\text { Loans and } \\
\text { interest } \\
\text { rate }\end{array}$} & Not familiar & 6 & 17 & 7 & 20 & 7 & 19 & 5 & 15 & 25 \\
\hline & $\begin{array}{l}\text { Just } \\
\text { Familiar }\end{array}$ & 30 & 83 & 28 & 80 & 30 & 81 & 29 & 85 & 117 \\
\hline \multirow[t]{2}{*}{ ATM } & Not familiar & 24 & 67 & 30 & 86 & 29 & 78 & 26 & 76 & 109 \\
\hline & $\begin{array}{l}\text { Just } \\
\text { Familiar }\end{array}$ & 12 & 33 & 5 & 14 & 8 & 22 & 8 & 24 & 33 \\
\hline \multirow{3}{*}{$\begin{array}{l}\text { Insurance } \\
\text { Products }\end{array}$} & Not familiar & 34 & 94 & 35 & 100 & 36 & 97 & 32 & 94 & 137 \\
\hline & $\begin{array}{l}\text { Just } \\
\text { Familiar }\end{array}$ & 02 & 06 & - & - & 01 & 03 & 02 & 06 & 05 \\
\hline & & 36 & 100 & 35 & 100 & 37 & 100 & 34 & 100 & $\begin{array}{c}142 \\
(100 \%)\end{array}$ \\
\hline
\end{tabular}

Source: Survey data

\section{Findings}

1. Majority of the respondents appear under an age group of below 25 (Youth)

2. Lions part of the respondents are female and having an educational background of primary level only.

3. Labor work is the major occupation and having an income level of below 5000 per month.

4. Majority (89\%) of the respondents have bank account in any bank.

5. No ample money to save is the major barrier in opening an account.

6. Around $62 \%$ of the respondents have knowledge about BSBDA scheme (No frills A/c)

7. Bank is acting as the major source of information for BSBDA

8. Media has no influence in creating the information about BSBDA

9. Soaring level of awareness about savings A/c, Pass Book, loans and interest etc.

10. The know how regarding ATMs and Insurance schemes are very low. (2\% and $4 \%$ respectively)

\section{Suggestions}

1. In case of ATM and insurance services, best part of the customers have only a little bit of knowledge. So the banks should organize various campaigning for enriching this knowledge.

2. BSBDA (No frills) should be tagged with Aadhar Enabled payment system(AEPS)

3. General ATMs are very essential in this vulnerable area and also Over Draft facility should also be ensure from BSBDA scheme.

4. Banking service centre are to be set up in various places of this vulnerable area for improving their savings habit. Then only the major constrain of (No money to save) for opening an account can be get rid of. 
5. Govt. should plan various schemes for banking the unbanked people living in this area by offering low interest rates, credit schemes, lower premium insurance products, pension schemes etc.

\section{Conclusion}

Financial inclusion and infrastructural development should go concurrently for evenhanded development of the deprived (vulnerable) groups living in the society. Banks should take necessary steps for attracting the BSBDA scheme through certain minimum common facilities. The services provided in this account should include deposit and withdrawal of cash at the bank branches as well as ATMs, credit of monetary benefits received under government schemes etc. Overall, the financial inclusion of these four vulnerable areas in Ernakulam district are acceptable. Some more effective steps from the part of government and banks may lead the district into a $100 \%$ financial inclusion zone.

\section{References}

1. Bekaert, Geert, Harvey Campbell R and Lundblad Christian (2005), "Does Financial liberalization spur growth”, journal of Financial Economics, volume 77, July 2005.

2. Goodwin D, Adelman L, Middleton S and Ashworth K (2000) "Debt, money management and access to financial services Evidence from 1999 PSE survey of Britain”, 1999 PSE survey working paper 8, Centre for Research in Social policy, Loughborough University.

3. Padmaja Mishra, Alok Ranjan Behera, Himanshu Sekhar Rout(2014), "Financial Inclusion, Inclusive growth and the poor". New century publication, New Delhi.

4. Prakash Kumar Sahoo and A lot Ranjan Behera(2014) "Finacial inclusion through Micro Finance" New century Publication, New Delhi, P -44.

5. Sharma Mandira(2008), "Index of Financial Inclusion" working paper, ICRIER, New Delhi.

6. V.V. Anilkumar and P.N. Harikumar(2015), "District Co-operative Banks and Financial Inclusion",Abhijeet Publications, New Delhi. 